\title{
Malignant Epididymal Neoplasm
}

National Cancer Institute

\section{Source}

National Cancer Institute. Malignant Epididymal Neoplasm. NCI Thesaurus. Code C3558.

A primary or metastatic malignant neoplasm that affects the epididymis. Representative examples include primary epididymal adenocarcinoma and metastatic carcinoma to the epididymis arising from another anatomic site. 